УДК 902.2 (477.73)

DOI: https://doi.org/10.33782/eminak2021.1(33).493

\title{
АРХЕОЛОГІЧНІ ПАМ'ЯТКИ КАЗАНКІВСЬКОГО РАЙОНУ МИКОЛАЇВСЬКОЇ ОБЛАСТІ (ЗА МАТЕРІАЛАМИ А.О. СІКОРСЬКОГО)
}

\author{
Тетяна Борисова 1 , Артем Борисов 2 \\ ${ }^{1}$ Національний університет «Києво-Могилянська академія» (Київ, Україна) \\ e-mail: borisovata@ukma.edu.ua; ORCID: https://orcid.org/0000-0002-1341-4902 \\ 2 Інститут археології НАН України (Київ, Україна) \\ e-mail: artem_borysov@iananu.org.ua; ORCID: https://orcid.org/0000-0002-2322-2277
}

У статті подається короткий аналіз підйомного матеріалу з археологічних поселень Повисуння, розташованих на території південної частини Казанківського району Миколаївської області, за даними польових щоденників першовідкривача - історика, вчителя Анатолія Олексійовича Сікорського. Обстеження пам'яток здійснювалося впродовж 1960-1980-х років. Зібрані науковцем матеріали в основному зберігаються у фондах Миколаївського обласного краєзнавчого музею та у Березнегуватському районному народному історико-краєзнавчому музеї.

Ключові слова: археологічна карта, поселенські пам'ятки, Повисуння, А.О. Сікорський, доба бронзи, Казанківський район

Степові простори території Північного Причорномор'я активно заселялися давніми племенами. Поселення в основному тяжіли до річок, як повноводних Південний Буг, Інгул, Інгулець, так і невеликих. Однією з них є р. Висунь, археологічні пам'ятки вздовж якої активно досліджував з 1960 по 1983 рр. історик, краєзнавець, вчитель Сергіївської восьмирічної школи Березнегуватського району Анатолій Олексійович Сікорський. Він співпрацював з співробітниками Інституту археології АН УРСР та Миколаївського обласного краєзнавчого музею. 3 останніми були реалізовані спільні археологічні експедиції у 1970-1980 pp. Зібрані матеріали А.О.Сікорський активно передавав у фонди Миколаївського обласного краєзнавчого музею.

На основі власних багаторічних досліджень А.О. Сікорський захистив у 1971 р. дипломну роботу на тему: «Історія племен бронзового віку Повисуння» на кафедрі історії Одеського державного університету імені I.I. Мечнікова. Дослідник є одним 3 авторів статті «Памятники Повисунья» 1997 р. ${ }^{1}$ На основі зібраних матеріалів опубліковано статтю «Археологічні пам'ятки біля с. Сергіївки на Миколаївщині (за матеріалами А.О. Сікорського)» (2018 р.)ㄹ. Частина археологічних пам'яток відкритих дослідником увійшла до низки каталогів і довідників з археології краю3. Проте,

\footnotetext{
1 Сикорский А.О., Елисеев В.Ф., Клюшинцев В.И. Памятники Повисунья // Сабатиновская и срубная культуры: проблемы взаимосвязей востока и запада в эпоху поздней бронзы. Тезисы докладов I-го Всесоюзного полевого семинара 10-18 сентября 1990 г. Киев-Николаев-Южноукраинск. С. 98-108.

2 Борисова Т.А., Борисов А.В. Археологічні пам'ятки біля с. Сергї̈вки на Миколаївщині (за матеріалами А.О. Сікорського) // Магістеріум. 2018. Вип. 70. Археологічні студії. С. 59-66.

3 Гребенников В.Б., Горбенко К.В. Поселения и грунтовые могильники эпохи бронзы на территории Николаевской области (археологическая карта). Николаев, 2010. 141 с.; Гребенников В.Б., Яценко С.М. Пам'ятки археології Казанківського району (каталог-довідник). Миколаїв: «Іліон», 2018.58 с.
} 
археологічна спадщина А.О. Сікорського до цього часу в повному обсязі не введена до наукового обігу.

У процесі розвідок Анатолій Олексійович вів польові щоденники, в яких фіксував кількість знахідок, описував і складав плани територій поселень. Щоденники збереглися за період 1960-1976 рр. На основі цих записів маємо можливість ввести до наукового обігу низку поселень Казанківського району Миколаївської області. Їх вивченість різна, оскільки А.О.Сікорський обстежував пам'ятки радіальними маршрутними розвідками від місця свого проживання (у 1960-61 р. с. Мар'янівка Казанківського району, з 1962 по 1983 - с. Сергіївка Березнегуватського району).

Виявлені поселення на території Казанківського району Миколаївської області у Повисунні переважно відносяться до періоду доби бронзи (сабатинівська, катакомбна, бабинська культури). Частину пам'яток за наявними знахідками можна віднести до доби неоліту та черняхівської культури (Володимирівка Совєтська Гребля I (п. 27-1963)). На території Казанківського району починаючи з 1960 р. А.О.Сікорський виявив і дослідив 28 різночасових поселень біля с. Мар'янівка: Мар'янівка I, Мар'янівка II, Мар'янівка III, Мар'янівка IV, Мар'янівка V, Мар'янівка Колгоспний Сад; с. Червона Новоселівка: Червона Новоселівка I, Червона Новоселівка II; с. Волна: Волна I; с. Рогозине: Рогозине I, Рогозине II, Рогозине III; с. Лагодівка: Лагодівка I, Фролівка I; с. Олександрівка: Олександрівка I, Олександрівка II; с. Володимирівка: Володимирівка I, Володимирівка II, Володимирівка III, Володимирівка IV, Володимирівка V , Володимирівка VI, Володимирівка VII, Володимирівка п. 18-1962, Степове (Широка Балка III), Володимирівка Совєтська Гребля I (п. 27-1963), Совєтська Гребля II, Новосілля I.

Матеріали щоденникових записів та авторські інвентарні польові списки дозволяють отримати базове уявлення про характер і кількісний склад кожної категорії підйомного матеріалу з перелічених пам'яток. Як правило, це фрагменти ліпної кераміки, вироби з каменю (зокрема різні категорії знарядь і решток виробництва з кременю), поодинокі вироби з бронзи, заліза, кістки. Окрему категорію матеріалів становлять фрагменти амфор (стінки, ручки). Детальність фіксації отриманої у полі інформації дозволяє реконструювати маршрути розвідок і час їх проведення. Цей цікавий приклад цілеспрямованого дослідження невеликої території потребує подальшого аналізу.

\section{Поселення біля села Мар'янівка.}

У районі села Мар'янівка виявлено шість поселень. До ранньосабатинівського типу віднесено поселення Мар'янівка I, Мар'янівка III. Поселення Мар'янівка II черняхівського типу.

1. Мар'янівка I. Поселення відкрите 19 вересня 1960 р. А.О. Сікорським. Розташоване на правому березі р. Висунь за 500 м. на південному сході від села. Поселення розтягнулося з півночі на південь по вододілу двох невеликих ярів. Постійно розорювалось.

На поверхні простежувалися сірі зольні плями з найбільшою кількістю ліпної кераміки, каміння, кісток тварин. Посуд ліпний, сірого й жовтуватого кольору, часто рівномірно обпалений, з шорсткою поверхнею, іноді залощений. Тісто у розломі чорного кольору з домішками піску, шамоту та товченого граніту. Характерна форма посуду банкоподібна з прямими або злегка відігнутим назовні вінчиками. Основний орнамент - валики, розчленовані защипами, нігтьовими вдавленнями та косими насічками. Зустрічаються вінчики прикрашені валиком, який зливається 3 
вінчиком. Ще один вид посуду з поселення - кубки з ручками, в яких у верхній частині знаходиться грибоподібний виступ. У розрізі ручки овальні, круглі або трикутні. Серед знахідок є уламки червоноглиняних амфор. У колекції зібраного ліпного посуду одинадцять вінчиків з валиками, вісім вінчиків з пальцевими вдавленнями, один 3 насічками по краю, а під вінчиком, по горловині посудини, хвиляста лінія 3 вдавлень. Ліпні посудини з різноманітними орнаментами: вдавленнями пальцями, штамп по валику з виступами, защипи, косі насічки, шишечкоподібні бугорки, хвилясті лінії. Є вінчики гончарного посуду.

Кремінь білий, молочного кольору часто ретушований. Серед крем'яних знахідок скребки. Інші знахідки: кістяна проколка, кістяна зламана пластинка з отвором, точило, залізний втульчатий трьохгранний наконечник стріли, камінь яйцевидної форми, частина зернотерки, диски з посуду, кам'яні млинчасті диски, кулі, гранітний молот. Частина зібраних матеріалів знаходиться у фондах Миколаївського обласного краєзнавчого музею4.

2. Мар'янівка II. Поселення відкрите 9 листопада 1960 р. Знаходиться на невисокому правому березі річки Висунь. За 200-300 м від села. Південна частина поселення розташована на крутому березі і пошкоджена кар'єром з видобутку щебеню та каменю, де були виявлені перші знахідки: кістяна проколка та фрагменти ліпного посуду, який стояв на невеликому обвугленому камінні. У кар'єрі знайдено плоске каміння, залишки обпаленої глини біля нього й обвуглені кістки тварин.

Кераміка на території поселення ліпна та кругова, якої два види: 1) не лощена 3 домішками дрібного каміння та крупних шматків білого кварцу, і 2) кругова без домішок, лощена з орнаментом з хвилястих ліній і трикутників, по п'ять лощених ліній у кожному та без орнаменту. Фрагменти кераміки різноманітного кольору: чорного, сірого, червоного. Знайдено чимало орнаментованого лощеного посуду але, в основному, без орнаменту. Один фрагмент з домішками графіту й орнаментований проколами гострою паличкою. Зібрано уламки амфор. У колекції фрагменти сіролощеної кругової кераміки, частини великих сіроглиняних піфосів 3 товщиною стінок до 16 мм. Столова кераміка тонка, орнаментована лощеними лініями. Фрагменти ліпних посудин грубі з великою кількістю піску та дрібних камінців. Зібрано шматки обпаленої глиняної обмазки зі слідами соломи та прутиків, черепки посуду з домішками графіту.

Серед кременю - наконечники, скребки. Інші знахідки: залізний рибальський гачок, точильний брусок з піщаника, наконечник стріли. Поселення черняхівського типу. Зібрані матеріали знаходиться у фондах Миколаївського обласного краєзнавчого музею5.

3. Мар'янівка III. Поселення відкрите 5 жовтня 1960 р. Розташоване на сході від села на лівому березі річки. На розораній поверхні простежувалась велика кількість зольних плям, будівельного каменю та кісток тварин. Основна кількість посуду ліпна, виготовлена з гарно розмішаної маси з домішками піску та шамоту. Колір кераміки світло сірий і жовтуватий, іноді чорний. Фрагменти посудин з слабо вираженим тулубом і баночних форм. Під вінчиком цього посуду є наліпний валик, розчленований косими надрізами або пальцевими вдавленнями. Чимало зібрано фрагментів чаш або мисок, а також кубків з ручками і яких грибоподібний виступ. Орнамент - розчленовані валики та пальцеві вдавлення.

\footnotetext{
4 Фонди Миколаївського обласного краєзнавчого музею: А-2625, КВ-10916.

5 Фонди Миколаївського обласного краєзнавчого музею: А-4706, КВ-19025.
} 
Серед інших знахідок: гранітна сокира з жолобчатим перехватом, кам'яні кулі, кам'яні млинчасті диски як з граніту, так і з річкового каменю, розтиральник, уламки зернотерок і мотики. Частина зібраних матеріалів знаходиться у фондах Миколаївського обласного краєзнавчого музею 6.

4. Мар'янівка IV. Поселення відкрите 8 січня 1961 р. Розташовано на лівому березі річки Висунь, на другій надзаплавній терасі. Невеликих розмірів. На території поселення є сліди жител. Основні знахідки крем'яні, світлого молочного кольору. Серед них трапеції, пластини-вкладки, скребки. Фрагменти ліпних черепків з тіста, яке містить домішки дрібного та крупного піску, іноді погано розмішане, з орнаментом відбитків шнура, крапочок та орнамент штампом у вигляді трикутників.

5. Мар'янівка V. Поселення відкрите 9 жовтня 1960 р. Розташоване на північ від поселення Мар'янівка II. На правому березі р. Висунь. Основні знахідки - кремінь, світлий, без патини (скребки, зламаний наконечник стріли, пластини, вкладиші). Кераміка ліпна, світло-жовта з домішками піску та графіту. $€$ фрагменти 3 глини темного кольору з домішками піску, на них орнамент ямками.

6. Мар'янівка Колгоспний Сад. Поселення відкрите 26 листопада 1960 р. Розташоване на першій надзаплавній терасі правого берега р. Висунь на території колгоспного саду між селами Мар'янівка та Лагодівка. При обстеженні знайдено кераміку ліпного посуду, заготовка кам'яної сокири. Крем'яні знахідки: скребла, наконечник стріли, рубило, гранітний молоток, молоток з річкового каменю.

\section{Поселення біля села Червона-Новоселівка.}

7. Червона Новоселівка I. Поселення відкрите 20 квітня 1970 р. Розташоване на захід від села, на правому березі р. Висунь. На поселенні знайдено велику кількість кременя серед знахідок пластини, вкладиші трапецевидної форми, скребки. Кераміка ліпна, тісто грубе з домішками шамоту, піску та графіту. Фрагменти ліпної кераміки орнаментовані шнуром і штампами.

8. Червона Новоселівка II. Поселення відкрите у травні 1970 p. Розташоване на правому березі річки на захід від села. Часті знахідки кременю (скребки, пластини, наконечник стріли з кременя). Кераміка ліпна, тісто з домішками крупного піску, частина фрагментів з домішками шамоту, графіту, мушель. Кольору чорного, сірого, іноді жовтого. Орнаментовані залишки посуду прокреслені штампом, розсічені насічками під різним кутом, вдавленнями шнуром, гострою паличкою, ямками, шишечками.

9. Лагодівка I. Поселення відкрите 21 вересня 1961 р. Розташовано на лівому березі р. Висунь у західній частині села Лагодівка. Після оранки невеликої ділянки знайдено кістки тварин, ліпна кераміка, каміння від будівель.

10. Фролівка I. Поселення відкрите 6 жовтня 1961 р. Розташовано на лівому березі р. Висунь. На схід від зниклого села Фролівка Лагодівської сільської ради, при впадінні у Висунь безіменної притоки. Основні знахідки - кераміка ліпного посуду, кремінь.

\section{Поселення біля села Волна.}

11. Волна I Поселення відкрите 2 травня 1966 р. Розташоване на східній околиці села на правому березі р. Висунь. Зі східної сторони поселення $\epsilon$ неглибокий яр. 3 південної - межує з річкою. Кераміка кругова, сіроглиняна, червоноглиняна, ло-

\footnotetext{
6 Фонди Миколаївського обласного краєзнавчого музею: А-2623, КВ-10914.
} 
щена з лінійним орнаментом. Зустрічається і ліпна, але дуже грубо зліплена, у тісті якої багато домішок кварцового піску, дрібних камінців. $Є$ фрагменти ребристих амфор. Знайдено кам'яну кулю, шматочок точильного каменю, шматок обпаленої глини з соломою та зерном, глиняне грузило для ткацького верстата. Всі зібрані матеріали були передані 4 листопада 1971 р. до фондів Миколаївського обласного краєзнавчого музею7.

\section{Поселення біля села Рогозине.}

12. Рогозине I. Поселення відкрите 2 червня 1966 р. Розташоване на південному сході за 300-400 м від села на лівому високому березі р. Висуні. На території поселення місцеві жителі видобували каміння. Кераміка плоскодонних ліпних посудин, шорохувата, іноді залощена з нерівномірно обпаленою поверхнею, жовтого, сірого та чорного кольорів. Тісто з домішками піску, шамоту. Вінчики посуду баночних форм зі злегка відігнутим зовні краєм, але трапився і загнутий до середини, з паралельними лініями. Фрагменти кераміки мали декор гребінчастим штампом, шишечкоподібними наліпами, валик, розчленований пальцевими вдавленнями, наскрізні отвори під вінчиком.

Інші знахідки: бронзовий уламок серпа та бронзовий злиток з отвором, два точильних каменя, кулеподібний камінь з місцевого вапняку.

13. Рогозине II. Поселення відкрите у квітні 1970 р. Розташовано уздовж лівого берегу р. Висунь. Зібрано велику кількість мікролітичного кременя переважно білого, молочного кольору (серед знахідок: пластини, різець, вкладиші, скребки), та фрагменти ліпної кераміки. У пухкому глиняному тісті домішки шамоту, кварцового піску, товченого граніту. Посуд декорований відбитками шнура, насічками: одна сторона вправо - одинадцять насічок косих, вліво - десять, друга сторона - вправо - тринадцять, вліво - дев'ятнадцять, потім - вправо тринадцять, знову вліво - чотири насічки. Зустрічаються врізні смуги, ямки нанесені лопаточкою, паралельні ямки, валики. Орнамент не чіткий, скорописний.

Серед інших знахідок $є$ бронзові: литий трьохлопасний наконечник стріли, фрагмент бронзового браслету з орнаментом насічками, три шматка бронзи (міді?), намистина з синього скла, два крем'яних наконечника, шматок графіту. Весь багатий зібраний матеріал передано А.О. Сікорським восени 1971 р. до фондів Миколаївського обласного краєзнавчого музею 8 .

14. Рогозине III. Поселення відкрите у березні 1972 р. Розташоване на західній околиці вже не існуючого села Рогозине на звивині річки правого берега у долині р. Висунь. Фрагменти кераміки дуже дрібні. Тісто з домішками піску, шамоту, крупного потовченого граніту, кварцу. Колір сірий, жовтий. Орнамент: вм'ятини у два ряди один за одним, вінчики з косими насічками. Цікавий фрагмент кругової посудини з зеленої глини з фрагментом ручки. Серед крем'яних знахідок вкладиші, пластинки, різці, скребки. Зустрічається кремінь чорного кольору.

\section{Поселення біля села Олександрівка.}

15. Олександрівка I. Поселення відкрите 27 червня 1965 р. Розташовано між с. Олександрівка та Мало-Василівка (нині Мотроно-Василівка) на південь від Олександрівки на високому лівому березі. На поселенні чітко видні сліди жител (скуп-

\footnotetext{
7 Фонди Миколаївського обласного краєзнавчого музею: А-4428, КВ-17605.

8 Фонди Миколаївського обласного краєзнавчого музею: А-2338, КВ-5735.
} 
чення каміння, кераміки та кісток тварин). Кераміка ліпна, плоскодонна, зі слідами загладжування, зовні червоного кольору. Вінчики оздоблені валиками, які розчленовані защипами, є орнамент з довгих паралельних надрізів. Інші знахідки: скляна намистина з блакитного скла у вигляді витягнутої краплі, кістяний штамп з трьома зубцями, фрагменти червоноглиняних амфор.

16. Олександрівка II. Поселення відкрите 2 червня 1966 р. Розташоване на лівому березі р. Висунь, на південно-східній околиці села. Межує з яром, а з півдня - 3 річкою. Кераміка ліпна, плоскодонна, добре обпалена, залощена, декорована валиками, насічками по вінцях, відтисками штампу. Знайдено вінчик з отвором наскрізь. Інші знахідки: кремінь, намистина з гранями з синього скла, кам'яна куля. Всі зібрані матеріали були передані до фондів Миколаївського обласного краєзнавчого музею9.

\section{Поселення біля села Володимирівка.}

17. Володимирівка I. Поселення відкрите відкрито 11 серпня 1964 р. науковим співробітником Миколаївського краєзнавчого музею В.I. Нікітіним. Подальше обстеження проводив А.О. Сікорський. Розташоване на правому березі р. Висунь біля самої води, поруч з греблею через річку, між селами Володимирівка та Новосілля. 3 заходу поселення межує з глибоким яром. Під час обстеження В.І.Нікітіним у 1964 р. знайдено залишки давньої гончарної печі. Піч мала конусовидну форму, обкладена камінням. Була заповнена золою та кістками. Кераміка з поселення ліпна, товстостінна і тонкостінна, орнаментована пальцевими вдавленнями, відтисками шнура. Опис дослідження подано у звіті В.І. Нікітіна ${ }^{10}$. Всі зібрані матеріали були передані до фондів Миколаївського обласного краєзнавчого музею11.

18. Володимирівка II. Поселення відкрите 12 серпня 1964 р. В.I. Нікітіним та А.О. Сікорським. Розташоване на правому високому березі р. Висунь вниз за течією. Знайдені вінця ліпної кераміки. Всі зібрані матеріали були передані до фондів Миколаївського обласного краєзнавчого музею12.

19. Володимирівка III. Поселення відкрите 19 березня 1961 р. Розташоване недалеко від с. Володимирівка на схилі глибокого яру на правому березі р. Висунь. На поверхні гарно простежуються зольні плями, каміння, кістки тварин. Плоскодонні посудини ліпної кераміки жовто-червоного та сірого кольорів, вироблені 3 гарно перемішаної глини з домішками піску та шамоту, мали загладжену поверхню зубчатим штампом. На розломі кераміка чорного кольору. Декоровані посудини розчленованими валиками, порізами, защипами, пальцевими вдавленнями, косими порізами, паралельними суцільними борозенками по всьому горщику, розчленованими насічками, штампом і шишечками. Переважають фрагменти посудин банкових форм з сильно відігнутим назовні та зрізаним у середину вінчиком. Плечики посудин прикрашені валиком, краї якого заходять один за одного або спускаються до низу валики гладенькі, або розчленовані косими насічками чи пальце-

\footnotetext{
9 Фонди Миколаївського обласного краєзнавчого музею: А-4429, КВ-17606.

10 Науковий архів Інституту археології НАН України. Ф. 64 (фонд експедицій). Оп. 1966. Спр. 40 (1966/40). № 4569: Никитин В.И. Отчет. Археологическая разведка в Николаевской области. Отчет Николаевской группы Одесского археологического общества об археологической разведке вдоль берегов реки Висунь Баштанского района Николаевской области за 1964, 1965, 1966 год. $31 \mathrm{c.}$

11 Фонди Миколаївського обласного краєзнавчого музею: А-7, КВ-2619.

12 Фонди Миколаївського обласного краєзнавчого музею: А-6, КВ-2619.
} 
вими вдавленнями. Траплялись фрагменти посудин типу кубків з характерними ручками з грибоподібними виступами.

Інші знахідки: кремінь, мідне шило, частина гранітної сверленої сокири, глиняна ніжка фігурки, кам'яні кулі, п’ять млинчастих дисків, зуби тварини, ріг кози, бронзовий наконечник стріли, світло зелена скляна намистина, ливарна форма, вісім фрагментів зернотерок з граніту, п'ять розтиральників. Всі зібрані матеріали були передані до фондів Миколаївського обласного краєзнавчого музею13.

20. Степове (Широка балка III). Поселення відкрите 8 листопада 1960 р. Розташоване по лівій стороні глибокого яру біля Машинно-тракторної станції (МТC) с. Володимирівки. Через північну його частину проходила польова дорога від с. Володимирівка до с. Озерівка. На його території помітна велика кількість крупного каміння та кераміки. Фрагменти ліпної кераміки з крупними домішками, залощені. Прикраса валиком переважає. Частина фрагментів декорована наліпками, квадратними отворами, розчленованим валиком, шишечкоподібним орнаментом, вм'ятинами пальцем. $Є$ кістки тварин.

Інші знахідки: частина гранітної зернотерки, млинчасті кам'яні диски, шлак, кремінь-нуклеус, кам'яний товкачик, гранітна куля.

21. Володимирівка п. 18-1962. Поселення відкрите 5 грудня 1962 р. розташоване на правому березі р. Висунь між селами Володимирівка та Сергіївка. На північний захід від володимирівського кам'яного кар'єру.

22. Володимирівка IV. Поселення відкрите 6 вересня 1964 р. Розташоване на мисі правого берега р. Висунь біля «Шарівської» греблі, вгору по яру до тваринницьких ферм, на північній околиці с. Володимирівка. На поверхні спостерігаються зольні плями, каміння, кістки тварин і ліпна кераміка, жовтого та червоного кольору, вироблена з гарно перемішаної глини з домішками піску, шамоту, польового шпату. Нерівномірно обпалена поверхня іноді має сліди лощення. У баночної форми посудин слабо відігнутий або прямий вінчик, ледве помітна горловина з наліпним або відтягнутим валиком, розчленованим пальцевими вдавленнями або насічками. Ще один тип посудин з відігнутим назовні вінчиком і добре виділеною горловиною. Орнаментовані косими порізами, паралельними борозенками, двома валиками, насічками. Всі зібрані матеріали були передані до фондів Миколаївського обласного краєзнавчого музею14.

23. Володимирівка V. Поселення відкрите 27 червня 1965 р. Розташоване на правому березі р. Висунь вниз за течією від с. Володимирівка на поливному колгоспному городі. Поруч гребля через Висунь. Зібрано дев'ятсот тридцять шість одиниць кременя молочного, жовтого іноді чорного кольору. Серед нього вісімдесят шість пластин, двадцять один скребок, п’ятдесят трапецій. Кераміка малочисельна, ліпна, грубо зліплена, товстостінна, внутрішні стінки посуду дуже чорного кольору, зовнішні - жовтуватого до червоного, з домішками піску, маловиразна. Декорована розчленованим валиком, відбитком шнура та лопаточкою. Вінчики з паралельними заглибинами, декілька з ялинковим орнаментом. Зібрані фрагменти червоноглиняних амфор.

Інші знахідки: наконечник стріли з кременя, сверлена шліфована сокира, два глиняних конічних пряслиця, трикутний крем'яний наконечник стріли, два фрагмента зернотерок, гудзик з річкової мушлі, заготовка наконечника стріли, точило 3 білого піщаника, частина зернотерки з сірого каменю, свинцеве пряслице.

\footnotetext{
13 Фонди Миколаївського обласного краєзнавчого музею: А-4671, КВ-18954.

14 Фонди Миколаївського обласного краєзнавчого музею: А-4694, КВ-19013.
} 
24. Володимирівка VI. Поселення відкрите 29 січня 1966 р. Розташоване на лівому березі р. Висунь на північ від поселення № 27. Вражає велика кількість фрагментів ручок амфор, фрагментів жовтого та червоного кольору, шлаку та ліпного посуду. Ліпна кераміка дуже крихка, грубо зліплена з прямими вінцями, з домішками кварцового піску.

Інші знахідки: частина кам'яної сокири, шлак.

25. Володимирівка VII. Перший запис про поселення у польових щоденниках А.О. Сікорського датований 14 лютого 1966 р. Розташоване західніше поселення Володимирівка Совєтська Гребля I (п. 27-1963), на лівому березі біля греблі, яка має назву «Совєтська». На протилежному правому березі знаходиться поселення Володимирівка V. Знайдено чимало кременя, серед них шість різців, шість скребків, дев'ять пластин. У керамічному тісті велика кількість домішок крупного кварцового піску та шматочків кварцу, а також графіту, товченої мушлі. Фрагменти посуду у розломі чорного кольору, дуже загладжені у середині та зовні. Орнаментація у вигляді відбитків шнура, штампом, невиразними заглибленнями рядами. Кісток тварин небагато. Кремінь в основному молочно-жовтого кольору.

Інші знахідки: точильце зі сланцю, зуб тварини, наконечник стріли з жовтого кременя, крем'яний наконечник списа, половинка скляної намистини блакитного кольору. У березні 1972 р. весь зібраний матеріал був переданий до фондів Миколаївського обласного краєзнавчого музею15.

26. Новосілля I (п. 8-1961). Поселення відкрите 20 березня 1961 р. Розташовано на північ від тваринницьких ферм села Новосілля Володимирівської сільської ради на полі. Частина поселення під виноградником. Місцеві жителі використовували камінь з поселення для будівництва. Зібрано кремінь, амфорну та ліпну кераміку, орнаментовану наліпним валиком. Знайдено кам'яний млинчастий диск.

27. Володимирівка Совєтська Гребля I (п. 27-1963). Поселення відкрите 14 листопада 1963 р. Розташовано на лівому березі р. Висунь на північ від греблі «Совєтской» між селами Володимирівка Казанківського району та Сергіївка Березнегуватського району. Велика кількість кераміки, переважно кругової, сіроглиняної, товстостінної, з домішками шамоту та піску, лощеної. Вінчики дуже відігнуті. Багато фрагментів амфор з жовтої та червоної глини. Ліпна кераміка груба, з погано просіяної глини, з домішками піску. Кераміка декорована паралельними лініями, валиками, відтисками шнура, орнаментом штампом з чотирьох паралельних ліній, ліній і крапочок. Глиняна обмазка зі слідами каміння, соломи та комишу жовтого та фіолетового кольору.

Інші знахідки: частина кованої залізної сокири, гранітний кулястий камінь, великі шматки обмазки з жител, грузило зі стінки амфори, частина точила, конусовидне глиняне пряслице, чотирнадцятигранна сіра намистина, кам'яна пробка для амфори.

У травні 1975 р. північну межу поселення було розорано. При обстеженні знайдено амфорну з жовтої глини кераміку, фрагменти гончарного, сіролощеного посуду, орнаментованого штампами, валиками під вінцем, полосами з кіл і трикутників, штампом з двох ліній з кругами у середині.

Серед інших знахідок: намистини: темно коричнева, п'ятигранна, бісерна синього кольору; язичок від бронзової фібули, шматки глиняної обмазки, глиняне грузило, точильний брусок, половинка пряслиця.

15 Фонди Миколаївського обласного краєзнавчого музею: А-4694, КВ-19013. 
28. Володимирівка Совєтська Гребля II. Пам'ятка розташована на лівому березі р. Висунь на північний схід від поселення Володимирівка Совєтська Гребля I (п. 27-1963). Знайдено амфорну кераміку. Ліпна, з домішками мушлі, прикрашена паралельними лініями. Зібрано кістки тварин, двохлопастний втульчатий і мідний наконечники стріл, крем'яні знаряддя праці.

Як бачимо, дослідження А.О. Сікорського заклали основу для археологічної карти Повисуння та, зокрема, південної частини Казанківського району (рис. 1). Здійснення повної публікації зібраних дослідником матеріалів і сучасне детальне документування відкритих археологічних пам'яток - справа майбутнього. Варто нагадати, що діяльність А.О. Сікорського певним чином дотична до феномену «громадянської науки» (citizen science), коли до наукових досліджень залучається широке коло добровольців. У випадку А.О. Сікорського зацікавлення давнім минулим краю переросло у професійну діяльність. Як відомо з спогадів односельців і родини вченого, його сучасники активно долучались до цих досліджень. Це добрий приклад співпраці суспільства та науки археології у справі дослідження археологічної спадщини України.

\section{REFERENCES}

Borysova, T. \& Borysov, A. (2018). Arkheolohichni pamiatky bilia s. Serhiivky na Mykolaivshchyni (za materialamy A.O. Sikorskoho) [Archaeological Sites near the village Sergiivka in Mykolaiv Region (on materials of A.A. Sikorsky)]. Mahisterium, 70: Arkheolohichni studii, 59-66 [in Ukrainian].

Grebennikov, V.B. \& Gorbenko, K.V. (2010). Poseleniia i gruntovye mogilniki epokhi bronzy na territorii Nikolaevskoi oblasti (arkheologicheskaia karta) [Settlements and Soil burial grounds of the Bronze Age on the territory of the Mykolaiv Region (archaeological map)]. Nikolaev [in Russian].

Hrebennykov, V.B., \& Yatsenko, S.M. (2018). Pamiatky arkheolohii Kazankivskoho raionu (katalohdovidnyk) [Archaeological Sites of Kazanka District (catalog-reference)]. Mykolaiv: Ilion [in Ukrainian].

Sikorskii, A.A., Nikitin, V.I., Eliseev, V.F. \& Kliushintsev, V.N. (1997). Pamiatniki Povisunia [The Sites of Povisunnia]. In: Sabatinovskaia i srubnaia kultury problemy vzaimosviazei vostoka i zapada v epokhu pozdnei bronzy. Kiev-Nikolaev-Yuzhnoukrainsk [in Russian].

\section{Tetiana Borysova}

(National University of Kyiv-Mohyla Academy, Kyiv, Ukraine)

e-mail: borisovata@ukma.edu.ua

ORCID: https://orcid.org/0000-0002-1341-4902

\section{Artem Borysov}

(Institute of Archaeology National Academy of Sciences of Ukraine, Kyiv, Ukraine)

e-mail: artem_borysov@iananu.org.ua

ORCID: https://orcid.org/0000-0002-2322-2277

\section{Archaeological Sites of Kazanka Raion of Mykolaiv Oblast (on materials of A.O. Sikorskyi)}

The paper gives a brief analysis of the surface finds from the archeological settlements of Vysun region located in the southern part of Kazanka Raion of Mykolaiv Oblast according to the field diaries of the discoverer - historian, teacher Anatolii Sikorskyi. Those sites were studied between 1960 and the 1980s. The materials collected by the researcher are mainly stored in the funds of Mykolaiv Regional Museum of Local History and Bereznehuvate Raion Folk History and Local Lore Museum. 
A.O. Sikorskyi's studies were the background for the archaeological map of Vysun region and in particular the southern part of Kazanka Raion. Sikorskyi's activity is in some way related to the phenomenon of 'citizen science', when a wide range of volunteers is involved in scientific research. In the case of A.O. Sikorskyi, the interest in the ancient past of the region grew into a professional activity. As we know from the memoirs of fellow villagers and the researcher's family, his contemporaries actively participated in those studies.

The paper introduced into scientific circulation a number of sites of Kazanka Raion in Vysun region as a part of the heritage of one of the researchers of Mykolaiv region archeological map. The current study is based on the private archive of the researcher.

Keywords: archeological map, settlement sites, Vysun region, A.O. Sikorskyi, Bronze Age, Kazanka Raion

Надійшла до редакції / Received: 07.09.2020

Схвалено до друку / Accepted: 13.02.2021

Інститут археології НАН України 


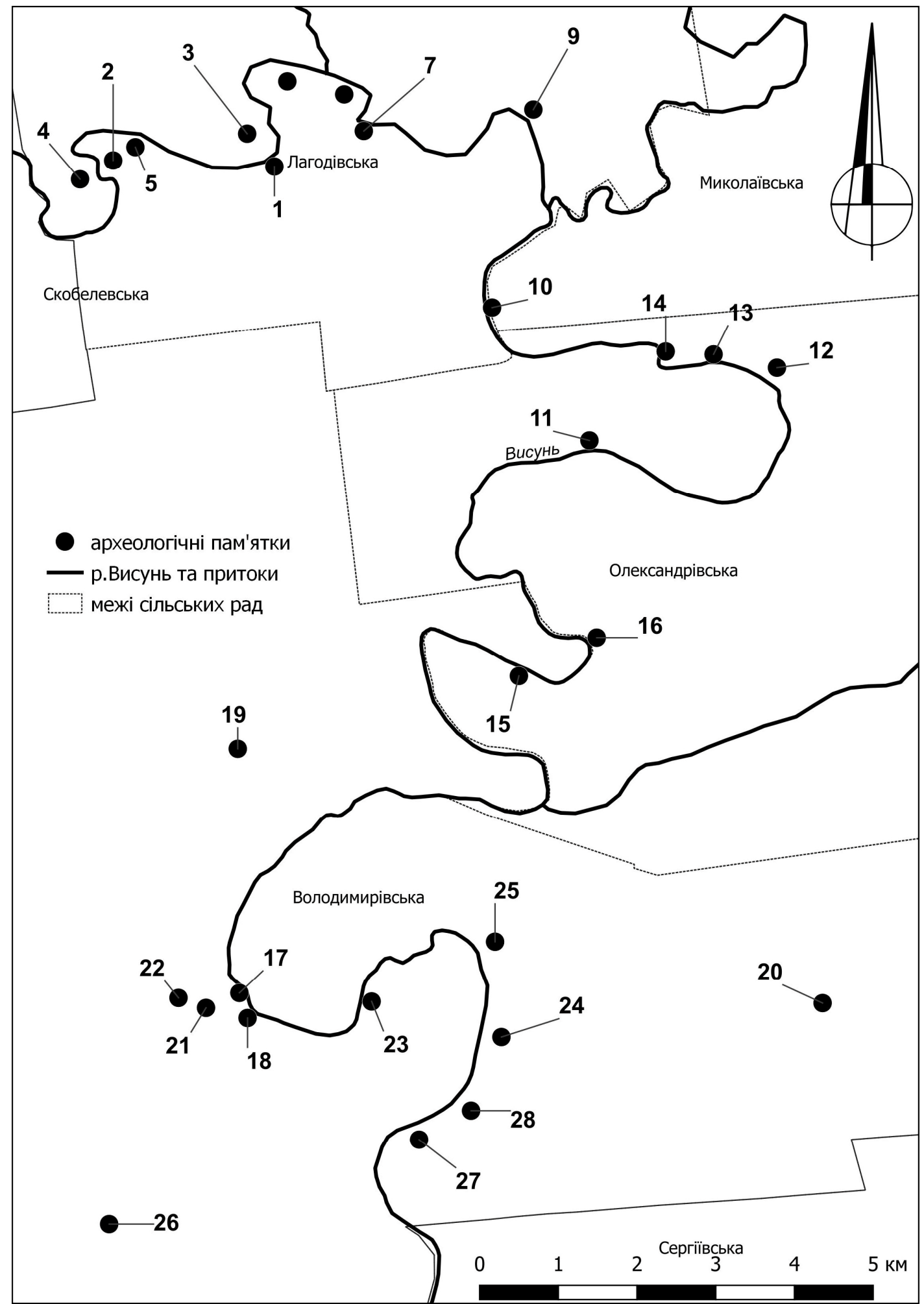

Рис. 1. Картосхема археологічних пам'яток Казанківського р-ну Миколаївської області за матеріалами А.О.Сікорського. 